\title{
Evaluation of metal removal performance of rod-type biosorbent prepared from sewage-sludge
}

\author{
Ji Hae Seo, Namgyu Kim, Munsik Park, Sunkyung Lee, Seungjae Yeon, Donghee Park ${ }^{\dagger}$ \\ Department of Environmental Engineering, Yonsei University, Wonju, 26493, South Korea
}

\begin{abstract}
The aim of this work was to evaluate the potential use of recycled sewage-sludge as a biosorbent for removing various metals from aqueous solution. To improve adsorption capacity and accomplish easy solid-liquid separation, the sludge was immobilized into the rod type with Ca-alginate. The removal performance was analyzed through kinetic and equilibrium studies. We conducted batch experiments examining the removal of cationic metals and anionic metals/metalloid by the rod-type biosorbent (cations: $\mathrm{Cd}(\mathrm{II}), \mathrm{Cu}(\mathrm{II}), \mathrm{Cr}(\mathrm{III}), \mathrm{Fe}(\mathrm{II}), \mathrm{Ni}(\mathrm{II}), \mathrm{Pb}(\mathrm{II}), \mathrm{Zn}$ (II), $\mathrm{Mn}$ (II), $\mathrm{Al}(\mathrm{III})$, $\mathrm{As}(\mathrm{III})$, and $\mathrm{Fe}(\mathrm{III})$; anions: $\mathrm{As}(\mathrm{V}), \mathrm{Cr}(\mathrm{VI})$ and $\mathrm{Mn}(\mathrm{VII}))$.The rod-type biosorbent, which was manufactured using sludge and alginate, showed higher adsorption capability for the removal of cationic metal than anionic metal. In evaluations of cation adsorption, divalent cations adsorbed more and faster than trivalent cations. The maximum uptake of $\mathrm{Cd}(\mathrm{II})$ was determined to be $67.29 \mathrm{mg} / \mathrm{g}$, which was higher than those of other sludge adsorbents reported in the literature. In evaluations of anions, $\mathrm{As}(\mathrm{V}), \mathrm{Cr}(\mathrm{VI})$ and $\mathrm{Mn}(\mathrm{VII})$ were removed by different mechanisms. In this study, we simultaneously evaluated the adsorption performance of a new biosorbent for cationic and anionic metals. Our findings are expected to contribute to the commercialization of sludge-based biosorbents.
\end{abstract}

Keywords: Biosorption, Ca-alginate, Heavy metals, Isotherm, Kinetic, Sewage-sludge

\section{Introduction}

Sewage-sludge, which is produced during the activated sludge process, contains numerous known and unknown hazardous materials such as pathogenic organisms, toxic organic pollutants and heavy metals. Conventional sewage-sludge treatment methods such as ocean dumping, landfilling and incineration are strictly regulated in many countries because of associated economic and environmental problems $[1,2]$. Therefore, the main problems of sludge disposal are related to the need to find and develop more efficient, economical and sustainable technologies for sludge disposal [3, 4].

Recently, alternative strategies such as biosorption have received significant attention. Biosorptionis defined to bind and concentrate selected ions as the property of biomass from aqueous solutions. This technology has been used as an alternative method of removing harmful toxic heavy metals by taking advantage of biological adsorption properties [5]. Biosorbents, or adsorbents used in biosorption, are prepared using various types of biomass including algae, aquatic plants, moss, bacteria, and sewage-sludge [6-8]. Sewage sludge is one of the most abundant types of microbial biomass. For this reason, there have been attempts to use it as a biosorbent [9-13] However, sewage-sludge has several disadvantages for use as a biosorbent such as the problem of maintenance of strength of biomass, separating suspended biomass from treated effluent, and inability to regenerate/reuse [10]. Therefore, immobilization technologies are commonly used to enhance its stability, mechanical strength, reusability, and ease of handling [14]. Various polymers are used for sewage-sludge immobilization. Among these, natural polymers such as alginate and chitosan are appropriate for immobilizing sewage-sludge as they are sustainable.

The biosorption of sewage-sludge for immobilization using alginate has been studied previously [15, 16]. A literature review indicates that there is a lack of studies examining biosorption of various metals using sewage-sludge, and that there are no reports that detail the removal mechanisms for different metals. The rapid development of various industries is causing more and more metals to contaminate the natural water environment. To commercialize biosorbent applications, it is essential to study the adsorption capacity for various heavy metals. In this study, we examined the adsorption of various heavy metals to meet requirements for decon-
This is an Open Access article distributed under the terms of the Creative Commons Attribution Non-Commercial License (http://creativecommons.org/licenses/by-nc/3.0/) which permits unrestricted non-commercial use, distribution, and reproduction in any medium, provided the original work is properly cited.

Copyright (C) 2020 Korean Society of Environmental Engineers
Received May 9, 2019 Accepted September 25, 2019

${ }^{\dagger}$ Corresponding author

Email: dpark@yonsei.ac.kr

Tel: +82-33-760-2435 Fax: +82-33-760-2571

ORCID: 0000-0001-5815-4545 
taminating water. Kinetic and equilibrium experiments were conducted to evaluate the removal mechanisms, biosorptive rates and adsorptive capacity of the biosorbent derived from sewage sludge by being immobilized with alginate.

\section{Materials and Methods}

\subsection{Preparation of Raw Biomass}

Sewage sludge, a complex consortium of microorganisms primarily consisting of bacteria, was collected from a university wastewater treatment plant (Wonju, Korea). It comprised 86\% water content and $14 \%$ solid content.

\subsection{Immobilization of Biomass}

First, $1 \mathrm{~g}$ (dried basis) of activated sludge was stirred in $100 \mathrm{~mL}$ distilled water. After mixing, $4 \mathrm{~g}$ of sodium alginate was added by continuous stirring. The mixture was extruded by syringe into $0.1 \mathrm{M}$ calcium chloride. The resulting rod-type biosorbents showed 0.3-0.4 mm in diameter (Fig. S1) and were maintained in the polymerizing medium for $4 \mathrm{~h}$. The rod-type biosorbents were washed in deionized water to leach out any excess solvents and then freeze-dried.

\subsection{Reagents}

Pure analytical grade Al(III), As(V), Cd(II), Cu(II), Cr(III), Cr(VI), $\mathrm{Fe}(\mathrm{II})$, $\mathrm{Ni}(\mathrm{II}), \mathrm{Mn}$ (II), $\mathrm{Mn}$ (VII), $\mathrm{Pb}$ (II) and $\mathrm{Zn}$ (II) solutions were prepared by dissolving solid $\mathrm{AlCl}_{3} \cdot 6 \mathrm{H}_{2} \mathrm{O}$ (Samchun, Korea), $\mathrm{Na}_{2} \mathrm{HAsO}_{4} \cdot 7 \mathrm{H}_{2} \mathrm{O}$ (Sigma-Aldrich, USA), $\mathrm{Cd}\left(\mathrm{NO}_{3}\right)_{2} \cdot 4 \mathrm{H}_{2} \mathrm{O}$ (Sigma-Aldrich, USA), $\mathrm{CuSO}_{4}$. $5 \mathrm{H}_{2} \mathrm{O}$ (Kanto, Japan), $\mathrm{CrCl}_{3} \cdot 6 \mathrm{H}_{2} \mathrm{O}$ (Sigma-Aldrich, USA), $\mathrm{K}_{2} \mathrm{Cr}_{2} \mathrm{O}_{7}$ (Junsei, Japan), $\mathrm{FeSO}_{4} \cdot 7 \mathrm{H}_{2} \mathrm{O}$ (Samchun, Korea), $\mathrm{NiCl}_{2} \cdot 6 \mathrm{H}_{2} \mathrm{O}$ (Samchun. Korea), $\mathrm{MnSO}_{4} \cdot \mathrm{H}_{2} \mathrm{O}$ (Samchun, Korea), $\mathrm{KMnO}_{4}$ (Samchun, Korea), $\mathrm{Pb}\left(\mathrm{NO}_{3}\right)_{2}$ (Kanto, Japen) and $\mathrm{ZnCl}_{2}$ (Samchun, Korea) in deionized water. All chemicals used in this studywere of analytical grade.

\subsection{Batch Experiments}

All experiments were carried out in $230 \mathrm{~mL}$ plastic bottles with constant agitation at $200 \mathrm{rpm}$ and room temperature $\left(20-25^{\circ} \mathrm{C}\right)$. For the evaluation of immobilization effect, $2 \mathrm{~g} / \mathrm{L}$ of immobilized sludge and raw sludge were contacted with $50 \mathrm{mg} / \mathrm{L}$ of deionized water for $12 \mathrm{~h}$. Batch biosorption experiments, including kinetic and equilibrium experiments, were conducted to evaluate the cationic and anionic metal adsorption of the rod-type biosorbents. In the kinetic experiment, $2 \mathrm{~g} / \mathrm{L}$ of biosorbent was contacted with $50 \mathrm{mg} / \mathrm{L}$ of each metal solution. In the case of cationic metal biosorption experiments, the solution was maintained at pH5. Experiments to study anionic metal/metalloid biosorption were conducted at pH2. Equilibrium experiments for isotherm study were performed in a similar manner to kinetic experiments, except that the initial metal concentrations were altered from 0 to 500 $\mathrm{mg} / \mathrm{L}$, which resulted in different equilibrium metal concentrations after $12 \mathrm{~h}$. In all batch experiments, the solution $\mathrm{pH}$ was maintained at the desired value using solutions of $1 \mathrm{M} \mathrm{HCl}$ and $1 \mathrm{M} \mathrm{NaOH}$. Samples were intermittently removed from bottles to analyze cationic or anionic metal concentration, following appropriate dilutions with deionized water.

\subsection{Measurements of Batch Adsorption Capacity, Isotherm and Kinetics}

The amount of metal contaminants adsorbed at equilibrium per unit mass of biosorbent $\left(q_{e}\right)$ was calculated using the equation:

$$
q_{e}(m g / g)=\frac{\left(C_{0}-C_{e}\right) V}{W}
$$

Where $C_{0}$ and $C_{e}$ are initial and equilibrium concentrations of adsorbate $(\mathrm{mg} / \mathrm{L})$, respectively, $W$ is the dry mass of the adsorbent (g), and $V$ is volume of the solution (L).

Kinetic models of pseudo-first order and pseudo-second order were used to comprehend the biosorption behavior of metals onto biosorbent in relation to time and to assess the rate of biosorption. Kinetic models can be exploited to investigate biosorption mechanism and potential rate-controlling step that may include mass transport and chemical reaction processes [17]. The pseudo-first order equation is given as:

$$
q_{t}=q_{e}\left(1-e^{-k_{1} t}\right)
$$

Where $q_{e}$ is the amount of adsorbate adsorbed (mg/g) at equilibrium, and $q_{t}$ is the amount of adsorbate adsorbed (mg/g) at time $t$ (min), and $k_{1}\left(\mathrm{~min}^{-1}\right)$ is the rate constants of the pseudo-first order biosorption. The pseudo-second order equation usually describes the situation when the rate of direct adsorption/desorption controls the overall sorption kinetics. The pseudo-second-order equation typically describes the removal behaviors of metals [18]. The integrated form of the pseudo-second-order equation is expressed as:

$$
\frac{t}{q_{t}}=\frac{1}{k_{2} \cdot q_{e}^{2}}+\frac{t}{q_{e}}
$$

whereh $(\mathrm{g} / \mathrm{mg} \times \mathrm{h})$ is initial sorption rate, and $k_{2}(\mathrm{~g} / \mathrm{mg} \times \mathrm{h})$ is the rate constant for the pseudo-second-order equation.

Biosorption isotherms represent the interactions between biosorbate and biosorbent, providing information about the distribution of biosorbate between liquid and solid phases in several equilibrium concentrations. Thus, isotherm modeling is important for biosorption data interpretation and prediction [19]. In this study, the isotherm models of Freundlich and Langmuir were used to evaluate biosorption equilibrium data. The Freundlich and Langmuir isotherm equation are in the forms:

$$
\begin{aligned}
& q_{e}=K_{F} C_{e}^{1 / n} \\
& q_{e}=\frac{q_{\max } b C_{e}}{1+b C_{e}}
\end{aligned}
$$

Where $K_{f}$ and $n$ are constants incorporating all parameters affecting biosorption in the Freundlich equation, and $b$ is the constant related to affinity of the binding sites in the Langmuir equation. In the Freundlich equation, $K_{F}(\mathrm{mg} / \mathrm{g})(\mathrm{L} / \mathrm{mg})^{1 / n}$ and $n$ (dimensionless) are Freundlich constants. On average, favorable adsorption conditions tend to have Freundlich constant $n$ between 1 and 10 , 
when Langmuir $q_{\max }$ is the maximum adsorption capacity (mg/g), and $b(\mathrm{~L} / \mathrm{g})$ is the Langmuir isotherm constant.

\subsection{Analytical Methods}

All samples were filtered through a $0.20 \mathrm{~mm}$ membrane before analysis. The total organic carbon (TOC) of the solution was measured using a TOC analyzer (TOC- $\mathrm{V}_{\mathrm{CPH} / \mathrm{CPN}}$, SHIMADZU, Japan). Total nitrogen (TN) and total phosphorous (TP) were determined using a test kit (C-MAC. Co., Korea).The infrared spectrum of the biosorbent was obtained using a Fourier transform infrared spectrometer (Vertex 70, Bruker). The total metal concentration was analyzed by inductively coupled plasma-optical emission spectrometry (ICP-OES, IRIS-Thermo Jarrell Ash Co., USA). Some metal was analyzed by a colorimetric method. The $\mathrm{Cr}(\mathrm{VI})$ concentration was spectrophotometrically analyzed at $540 \mathrm{~nm}$ according to a standard method using 1,5-diphenylcarbazide [20]. The pink color of Mn(VII) alone was analyzed at $525 \mathrm{~nm}$ for measuring concentrations [21].

\section{Results and Discussion}

\subsection{Evaluation of Immobilization Methods}

One of the most important reasons to use immobilization techniques when preparing biomass is that it improves the stability of the material for industrial applications. This stability can be measured as TOC released from the biosorbent during pretreatment with a deionized-distilled water wash. TOC is often used as a non-specific indicator of water quality. The raw biosorbent (activated sludge) is composed of microorganisms such as bacteria, fungi, yeasts, algae, and protozoa [22]. Therefore, the primary composition of the biomass can be easily dissolved in water due to its organic content. For this reason, use of raw biosorbent can lead to secondary organic material contamination, which could be solved by improving the stability of the biosorbent through immobilization. The amounts of TOC released from the rod-type biosorbent are much lower than those for raw biosorbent (Table S1: $5.77 \mathrm{mg}-\mathrm{C} / \mathrm{L}$ vs.
$26.66 \mathrm{mg}-\mathrm{C} / \mathrm{L})$. These results demonstrate that immobilization technique used in this study improves the stability of biosorbent. In addition, an advantage of this method is the enhancing effect of alginate on cationic removal. According to past studies, the carboxyl group of alginate can efficiently bind cationic heavy metals [23]. The biosorbent used in this study also had a carboxyl group, indicating that cation sorption capacity was improved (Fig. S2 and Table S2). For practical application of the biosorbent, its mechanical stability was also examined. There was no destruction of the biosorbent under experimental conditions of this study.

\subsection{Removal of Cationic Metal by Rod-type Biosorbents}

In a previous paper, the performance of biosorbents was evaluated for only one or two metals. However, there are many kinds of metals in the environment. For this reason, we evaluated the performance of the biosorbent for a variety of individual metals as well as its potential utility as a cation heavy metal adsorbent. To study adsorptive capacity and to understand the mechanism underlying the function of rod-type biosorbent, we performed kinetics and isotherms studies.

Firstly, we conducted a kinetic study to provide detailed information for biosorbate uptake rate and the rate-controlling step for each metal. This type of experiment is most important when designing batch sorption systems. Fig. 1 shows concentration profiles of divalent metals (Cd(II), Cu(II), Fe(II), Ni(II), Mn(II), Pb(II) and $\mathrm{Zn}(\mathrm{II})$ ) and trivalent metals ( $\mathrm{Al}(\mathrm{III})$ and $\mathrm{Cr}(\mathrm{III})$ ) versus agitation time using the rod-type biosorbent at $\mathrm{pH}$ 5. To quantitatively describe the kinetic behaviors of divalent metals and trivalent metals during the biosorption process, pseudo-first order and pseudo-second order adsorption kinetic equations were used to fit the batch kinetic data, following the expressions in Eqs. (2)-(4). Based on the equations for the different metals, we calculated the values of rate constant, initial sorption rate, and coefficients and are presented in Table 1 . The $\mathrm{R}^{2}$ values are higher than those of the pseudo first-order model and indicate that the pseudo-second order kinetic model is a better fit for describing biosorption kinetics of the heavy metals analyzed in this study onto rod-type biosorbent.
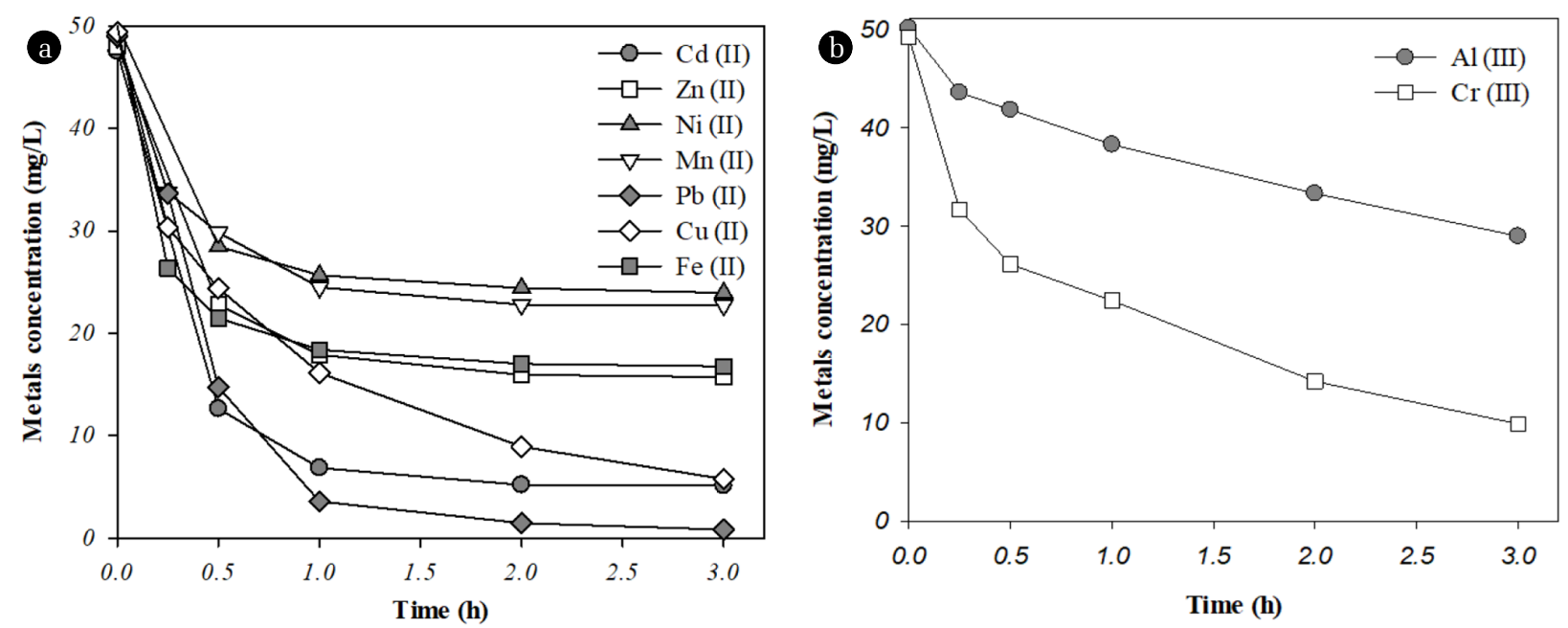

Fig. 1. Dynamics of cation metals removal by rod-type biosorbent: (a) Cation (II) $(\mathrm{Cd}(\mathrm{II}), \mathrm{Zn}(\mathrm{II}), \mathrm{Ni}(\mathrm{II}), \mathrm{Mn}(\mathrm{II}), \mathrm{Pb}(\mathrm{II}), \mathrm{Cu}(\mathrm{II}), \mathrm{Fe}(\mathrm{II}))$ and (b) Cation (III) (Al(III), Cr(III)). (Batch experiment condition: metal concentration $=50 \mathrm{mg} / \mathrm{L}$, [biosorbent] $=2 \mathrm{~g} / \mathrm{L}, \mathrm{pH}=5.0$, contact time $=3.0 \mathrm{~h}$ ) 
This indicates that cation metals adsorption is a chemisorption process involving valency forces through the sharing or exchange of electrons between rod-type biosorbent and cation metal ions acting as covalent forces [24]. Ca-alginateimmobilized inactive biomass has known that to some extent carboxyl groups $(-\mathrm{COOH})$ are responsible for the binding ofmetal ions at higher $\mathrm{pHs}$ (above 4), which attract the positively charged metal ions and binding occurs. Thus, heavy metal ion binding to the biomass surface is an electrostatic interaction mechanism, between metallic cations and the negatively charged groups in the biomass surface.

When comparing equilibrium uptake values, $q_{e}, \mathrm{~Pb}(\mathrm{II})$ presented the highest value of $28.23 \mathrm{mg} / \mathrm{g}$ according to the pseudo-second order adsorption kinetic equations (Table 1). However, the uptake value of $\mathrm{Pb}$ (II) was not explained solely by sorption, because precipitation of the $\mathrm{Pb}(\mathrm{II})$ hydroxides partially occurs at $\mathrm{pH}$ 5. Based on a comparison of initial sorption rate, $h$, between the metal ions studied, the following tendency concerning hard and soft metal cations was observed: $\mathrm{Cd}$ (II) $>$ Fe(II) $>\mathrm{Zn}$ (II) $>\mathrm{Ni}$ (II) $>\mathrm{Mn}$ (II) $>\mathrm{Pb}$ (II) $>\mathrm{Cu}(\mathrm{II})>\mathrm{Cr}(\mathrm{III})>\mathrm{Al}(\mathrm{III})$.

The relationship between metal uptake and sorbate equilibrium concentration at a constant temperature is known as the adsorption isotherm. There are many expressions that describe adsorption isotherms, the most common of which are the Freundlich and Langmuir models, following Eq. (4) and (5). Freundlich and Langmuir isotherms describe the adsorption of inorganic compounds on a wide variety of adsorbents including biosorbent [25]. Isotherm simulations from the Freundlich and Langmuir models of cationic heavy metals for rod-type biosorbent are shown in Fig. 2. The values of Freundlich and Langmuir isotherm constants are given in Table 2. After comparing the linear correlation coefficients shown in Table 2, most cationic metal ions have similar $\mathrm{R}^{2}$ values between the two models or the Langmuir model fits better except

Table 1. Pseudo-first-order and Pseudo-second-order Model Parameter Values of Various Metals

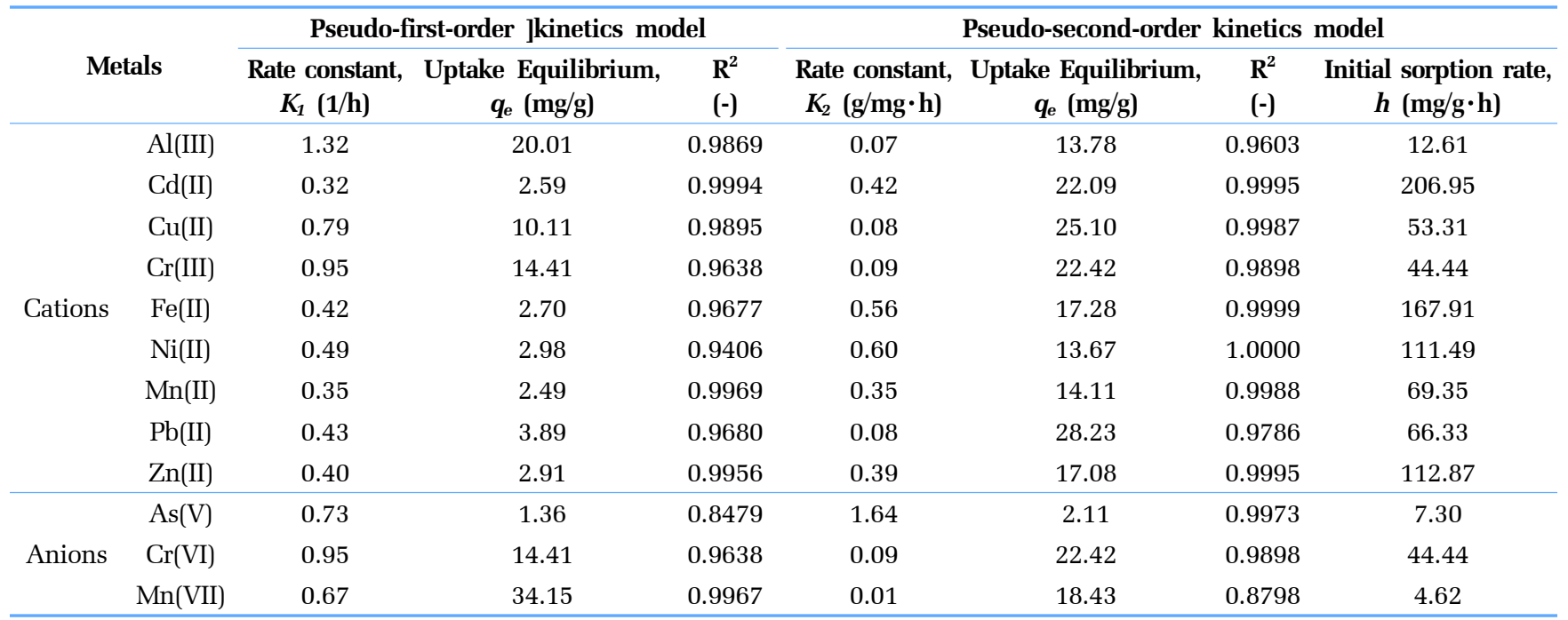

Table 2. Langmuir and Freundlich Model Parameter Values of Various Metals

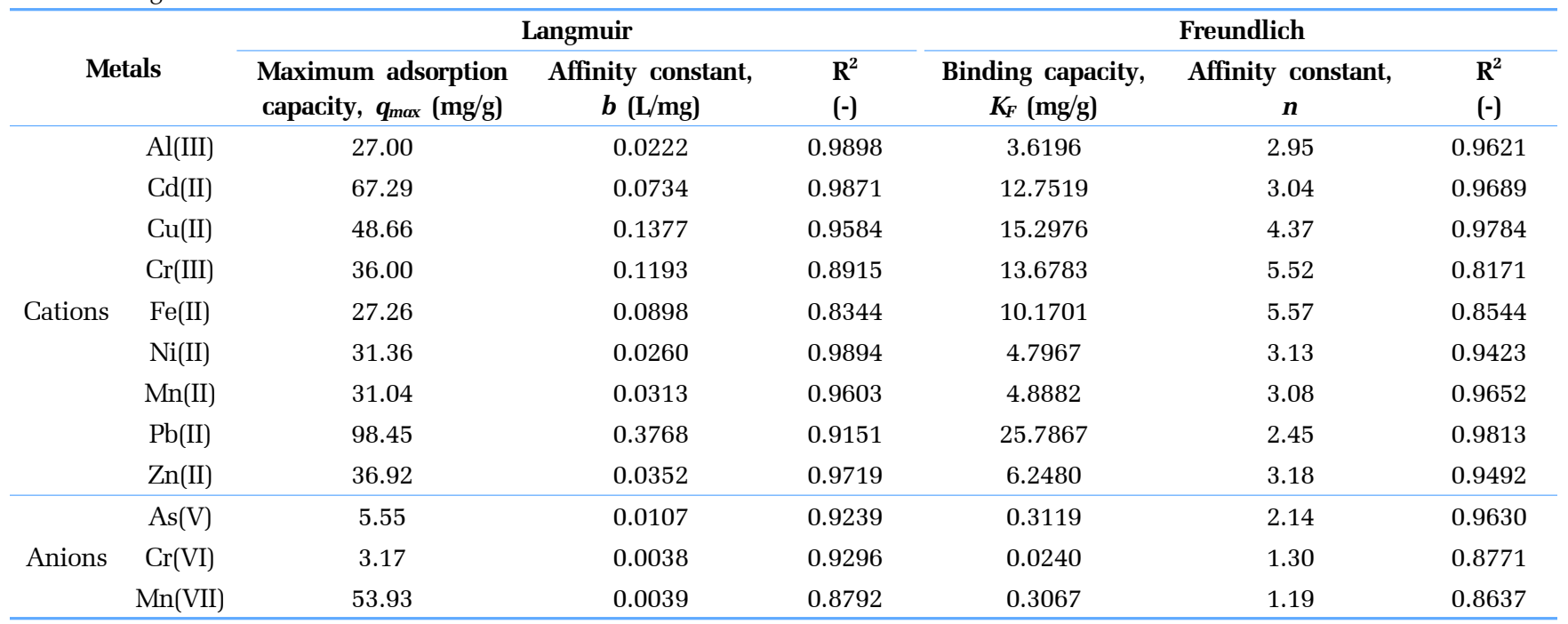



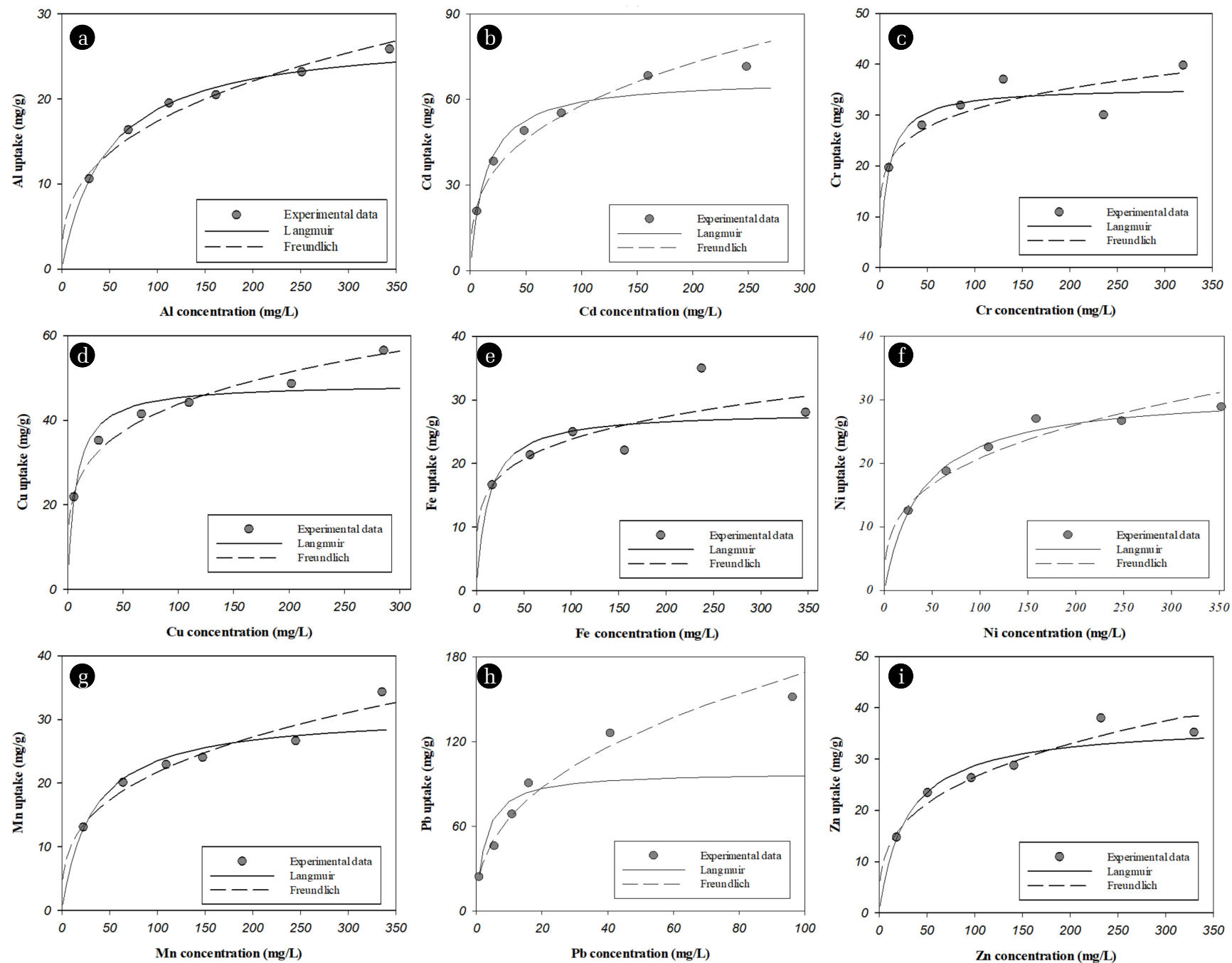

Fig. 2. Equilibrium isotherm of cation metal adsorption by rod-type biosorbent. (a): $\mathrm{Al}(\mathrm{III}),(\mathrm{b})$ : $\mathrm{Cd}(\mathrm{II}),(\mathrm{c}): \mathrm{Cu}(\mathrm{II}),(\mathrm{d}): \mathrm{Cr}(\mathrm{III}),(\mathrm{e})$ : $\mathrm{Fe}(\mathrm{II}),(\mathrm{f})$ : $\mathrm{Ni}(\mathrm{II})$, (g): $\mathrm{Mn}(\mathrm{Il}),(\mathrm{h}): \mathrm{Pb}(\mathrm{Il}),(\mathrm{i}): \mathrm{Zn}(\mathrm{Il})$, Batch experiment conditions : [biosorbent] $=2 \mathrm{~g} / \mathrm{L}, \mathrm{pH}=5.0$, contact time $=9.0 \mathrm{~h}$.

Table 3. Maximum uptakes of $\mathrm{Cd}(\mathrm{II})$ by biosorbents manufactured from sludge

\begin{tabular}{|c|c|c|c|}
\hline Sorbent type & Uptake (mg/g) & Experimental condition & Reference \\
\hline Activated sludge (Domestic) & 28.10 & $\mathrm{pH} 5,2 \mathrm{~h}$ & {$[10]$} \\
\hline Clarified sludge (Industry) & 36.23 & $\mathrm{pH} 5,2 \mathrm{~h}$ & {$[11]$} \\
\hline Activated sludge (Domestic) & 40.24 & $\mathrm{pH} 6,2 \mathrm{~h}$ & {$[12]$} \\
\hline Sewage-sludge (Domestic) & 28.41 & $\mathrm{pH} 5,24 \mathrm{~h}$ & {$[13]$} \\
\hline Sludge Ca-alginate (Domestic) & 67.29 & $\mathrm{pH} 5,6 \mathrm{~h}$ & This study \\
\hline
\end{tabular}

for $\mathrm{Pb}(\mathrm{II})$. As mentioned above, $\mathrm{Pb}(\mathrm{II})$ was precipitated under experimental condition. The Freundlich isotherm shows adsorption-complexation reactions during the adsorption process [26]. The present study demonstrates that the value of $\mathrm{R}^{2}$ for the Freundlich model was higher than that of the Langmuir model. It is generally accepted that the Langmuir model describes monolayer adsorption with specific adsorption onto functional binding sites at the adsorbent [27]. According to Table 2, the maximum sorption capacity $\left(q_{\max }\right)$ was highest for sorption of $\mathrm{Pb}(\mathrm{II})$. Although the Langmuir constant $q_{\max }$ is dependent on experimental conditions, it is a good measure for comparing different sorbents for the same biosorbate. The $q_{\max }$ value was 67.29 for $\mathrm{Cd}(\mathrm{II})$, which was higher than in previous studies of biosorbents of sludge (Table 3). The Langmuir maximum metal sorption capacity of other metals decreased in the following order: $\mathrm{Pb}(\mathrm{II})>\mathrm{Cd}(\mathrm{II})>\mathrm{Cu}$ (II) $>\mathrm{Zn}$ (II) $>\mathrm{Cr}(\mathrm{III})>\mathrm{Ni}(\mathrm{II})>\mathrm{Mn}(\mathrm{II})>\mathrm{Fe}(\mathrm{II})>\mathrm{Al}(\mathrm{III})$. 


\subsection{Removal of Anionic Metalloid/Metals by Rod-type Biosorbent}

While a large amount of cation heavy metal is present in aqueous solution, the importance of anions is a growing concern in the field. Anions such as arsenate $\left(\mathrm{HAsO}_{4}{ }^{2-}\right.$ or $\mathrm{H}_{2} \mathrm{AsO}_{4}^{-}$: $\mathrm{As}(\mathrm{V})$ ), chromate $\left(\mathrm{CrO}_{4}{ }^{2-}: \mathrm{Cr}(\mathrm{VI})\right)$ and permanganate $\left(\mathrm{MnO}_{4}^{-}: \mathrm{Mn}(\mathrm{VII})\right)$ are conventionally removed by ion exchange, precipitation, or activated carbon sorption [28]. For this reason, we applied rod-type biosorbent for further biosorption studies of extended anionic metalloid/metals species. To understand the mechanisms and sorption capacities of the rod-type biosorbent, we conducted kinetics and isotherm studies for anion species. Fig. 3 is a plot of experimental data points for the sorption of arsenate, chromate, and manganese oxide on rod-type biosorbents as a function of time at $\mathrm{pH} 2$. It is generally accepted that the mechanism of anion biosorption is adsorption by electrostatic attraction at low $\mathrm{pH}$.

Amine groups in biomass play important roles as key sites for anionic metal sorption. FTIR analyses of the rod-type biosorbent indicated that there were few amide groups (Fig. S2 and Table S2). However, as shown in Fig. 3, Mn(VII) concentration sharply decreased, and $\mathrm{Mn}(\mathrm{VII})$ was completely removed from the aqueous solution. To examine the Mn(VII) removal characteristics of the rod-type biosorbent, we investigated the total manganese concentrations (Fig. 4). After complete Mn(VII) removal, $30 \mathrm{mg} / \mathrm{L}$ of total Mn was bound to the rod-type biosorbent. Comparison of model fitting data could explain the mechanism for sorption, and those of $\mathrm{Mn}(\mathrm{VII})$, as shown in Table 1, was considerably higher for the pseudo-first-order kinetic model. The sorption of $\mathrm{Mn}$ (VII) did not fit any isotherm model (Table 2). The Mn(VII) removal mechanism is different from those of other metals. Naturally, $\mathrm{Mn}$ (VII) is stable in neutral or slightly alkaline solution. The exact chemical reactions occur in a manner dependent upon the organic contaminants present and the oxidant utilized. In acidic solution, $\mathrm{Mn}(\mathrm{VII})$ is reduced

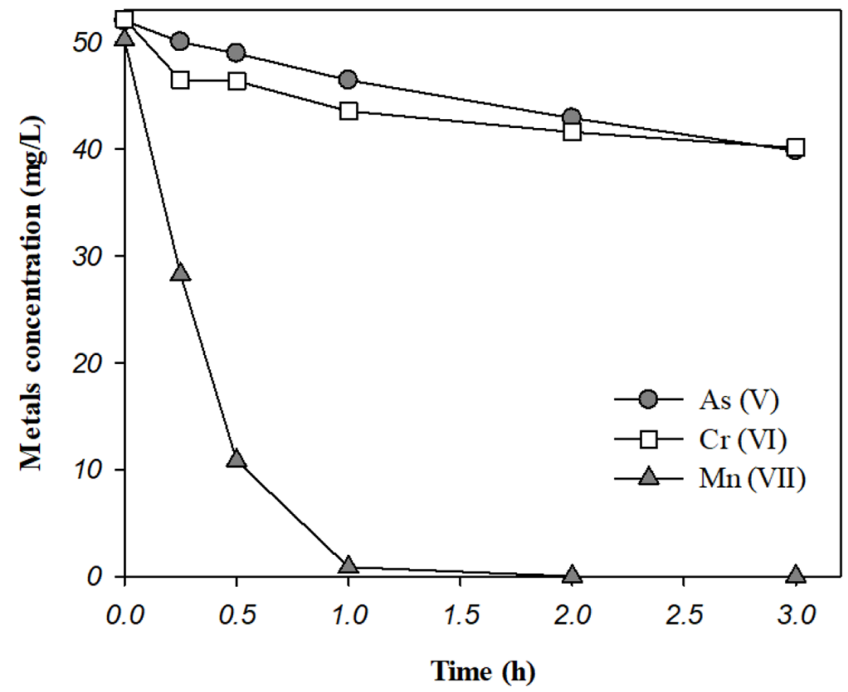

Fig. 3. Dynamics of anionic metal removal by rod-type biosorbent: $\mathrm{As}(\mathrm{V}), \mathrm{Cr}(\mathrm{VI})$ and $\mathrm{Mn}(\mathrm{VII})$. (Batch experiment conditions: metal concentration $=50 \mathrm{mg} / \mathrm{L}$, [biosorbent $]=2 \mathrm{~g} / \mathrm{L}, \mathrm{pH}=2.0$, contact time $=3.0 \mathrm{~h}$ ).

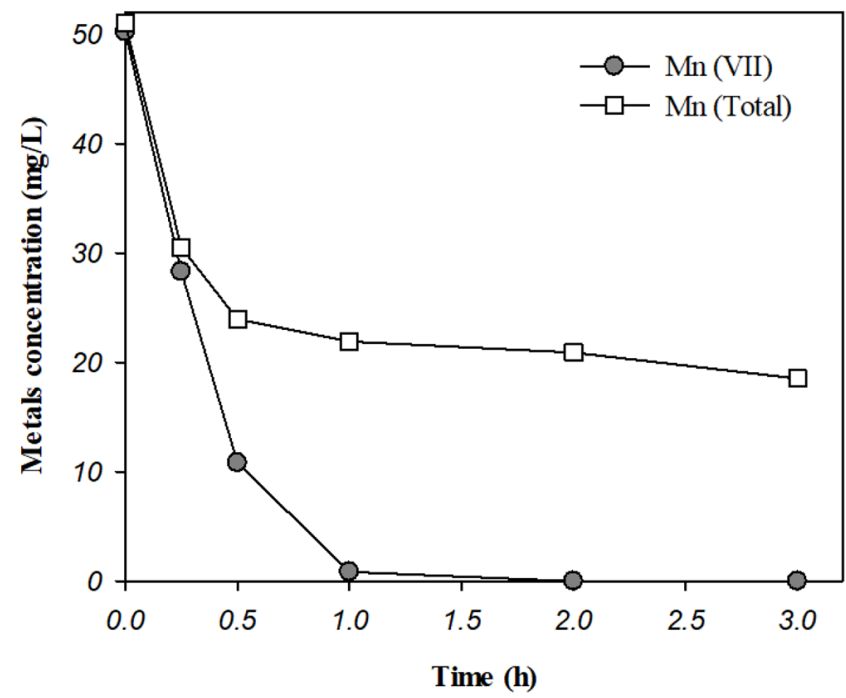

Fig. 4. $\mathrm{Mn}$ concentrations profiles during $\mathrm{Mn}(\mathrm{VII})$ biosorption.

to the colorless +2 oxidation state of the $\mathrm{Mn}$ (II) $\left(\mathrm{Mn}^{2+}\right)$ ion, which binds to negatively charged groups in the rod-type biosorbent. For this reason, the biosorption mechanism of anionic Mn(VII) at low $\mathrm{pH}$ is believed to be adsorption-coupled reduction.

As mentioned above, adsorption isotherms are used for the design of adsorption systems. The Langmuir and Freundlich adsorption isotherm models have been used for describing the anion adsorption isotherm. Table 2 presents the adsorption parameters of Langmuir and Freundlich as calculated for biosorption of $\mathrm{As}(\mathrm{V})$ and $\mathrm{Cr}(\mathrm{VI})$ on rod-type biosorbent. The Langmuir and Freundlich adsorption isotherm results are shown in Fig. 5.The Langmuir isotherm constants are given in Table 2. The equilibrium monolayer capacity, $q_{\max }$, was $5.55 \mathrm{mg} / \mathrm{g}$ for $\mathrm{As}(\mathrm{V})$ ions and $3.17 \mathrm{mg} / \mathrm{g}$ for $\mathrm{Cr}(\mathrm{VI})$ ions. There was virtually no binding to the rod-type biosorbent for adsorption of anions.

\section{Conclusions}

Rod-type biosorbent prepared from activated sludge and alginate is a low cost, easily accessible and complex biosorbent. Because a variety of toxic metallic species are found in natural waterways and in wastewater, we investigated cationic and anionic heavy metals as a single system. A rod-type biosorbent manufactured from sludge and alginate achieved higher adsorption capability for removal of cationic metal than removal of anionic metal. Most of the metals were well fit by the pseudo-second-order and Langmuir models. For cationic metals, the maximum metal uptake was as follows: $\mathrm{Pb}(\mathrm{II})>\mathrm{Cd}(\mathrm{II})>\mathrm{Cu}(\mathrm{II})>\mathrm{Zn}$ (II) $>\mathrm{Cr}$ (III) $>\mathrm{Ni}(\mathrm{II})>$ $\mathrm{Mn}(\mathrm{II})>\mathrm{Fe}$ (II) $>\mathrm{Al}(\mathrm{III})$. The maximum uptake of $\mathrm{Cd}(\mathrm{II})$ was determined to be $67.29 \mathrm{mg} / \mathrm{g}$, which was higher than those of other sludge adsorbents reported in the literatures. Different anionic metals were removed by different mechanisms, and binding to the rod-type biosorbent was poor. Our results indicate that different metals have different removal mechanisms depending on the metal characteristics. 


\section{Acknowledgments}

This work was supported by Korea Ministry of Environment through grants from the KEITI (the Eco-Innovation Project, 2012000150005).

\section{Author Contributions}

J.H.S. (Ms. student) conducted most of the experiments. M.P. (Dr.), S.L. (Ph.D. student) and S.Y. (Ph.D. student) conducted some of the experiments. N.K. (Dr.) and D.P. (Professor) wrote the manuscript.

\section{References}

1. Laurent J, Casellas M, Carrère H, Dagot C. Effects of thermal hydrolysis on activated sludge solubilization, surface properties and heavy metals biosorption. Chem. Eng. J. 2011;166:841-849.

2. Raheem A, Sikarwar VS, He J, et al. Opportunities and challenges in sustainable treatment and resource reuse of sewage sludge: A review. Chem. Eng. J. 2018;337:616-641.

3. Hong J, Hong J, Otaki M, Jolliet O. Environmental and economic life cycle assessment for sewage sludge treatment processes in Japan. Waste Manage. 2009;29:696-703.

4. Lee ME, Jeon P, Kim J-G, Baek K. Adsorption characteristics of arsenic and phosphate onto iron impregnated biochar derived from anaerobic granular sludge. Korean J. Chem. Eng. 2018;35:1409-1413.

5. Park D, Yun YS, Park JM. The past, present, and future trends of biosorption. Biotechnol. Bioproc. E. 2010;15:86-102.

6. Choi HJ, Yu SW. Biosorption of methylene blue from aqueous solution by agricultural bioadsorbent corncob. Environ. Eng. Res. 2019;24:99-106.

7. Vera LM, Bermejo D, Uguna MF, Garcia N, Flores M, Gonzalez E. Fixed bed column modeling of lead(II) and cadmium(II) ions biosorption on sugarcane bagasse. Environ. Eng. Res. 2019;24:33-37.

8. Yous R, Mohellebi F, Cherifi H, Amrane A. Competitive biosorption of heavy met8als from aqueous solutions onto Streptomyces rimosus. Korean J. Chem. Eng. 2018;35:890-899.

9. Ghorpade A, Ahammed MM. Water treatment sludge for removal of heavy metals from electroplating wastewater. Environ. Eng. Res. 2018;23:92-98.

10. Hammaini A, González F, Ballester A, Blázquez ML, Muñoz JA. Biosorption of heavy metals by activated sludge and their desorption characteristics. J. Environ. Manage.2007;84:419-426.

11. Naiya TK, Bhattacharya AK, Das SK. Removal of Cd(II) from aqueous solutions using clarified sludge. J. Colloid. Interf. Sci.2008;325:48-56.

12. Kusvuran E, Yildirim D, Samil A, Gulnaz O. A Study: Removal of $\mathrm{Cu}(\mathrm{II}), \mathrm{Cd}(\mathrm{II})$, and $\mathrm{Pb}(\mathrm{II})$ ions from real industrial water and contaminated water using activated sludge biomass. Clean Soil
Air Water 2012;40:1273-1283.

13. Hu JL, He XW, Wang CR, Li JW, Zhang CH. Cadmium adsorption characteristic of alkali modified sewage sludge. Bioresour. Technol.2012;121:25-30.

14. Sudha Bai R. Abraham TE, Studies on chromium(VI) adsorption -desorption using immobilized fungal biomass. Bioresour. Technol. 2003;87:17-26.

15. Wu HS, Zhang AQ, Wang LS. Immobilization study of biosorption of heavy metal ions onto activated sludge. J. Environ. Sci. 2004;16:640-645.

16. Paul CJ, Lie D, Wang L, Wu S, Zhang B. Dried waste activated sludge as biosorbents for metal removal: adsorptive characterization and prevention of organic leaching. J. Chem. Technol. Biotechnol. 2002;77:657-662.

17. Bayramoglu G, Arica MY. Adsorption of congo red dye by native amine and carboxyl modified biomass of Funaliatrogii: Isotherms, kinetics and thermodynamics mechanisms. Korean J. Chem. Eng. 2018;35:1303-1311.

18. Kim TK, Kim T, Choe WS, Kim MK, Jung YJ, Zoh KD. Removal of heavy metals in electroplating wastewater by powdered activated carbon (PAC) and sodium diethyldithiocarbamate-modified PAC. Environ. Eng. Res. 2018;23:301-308.

19. Ho YS, Huang CT, Huang HW. Equilibrium sorption isotherm for metal ions on tree fern. Process Biochem. 2002;37:1421-1430.

20. Park D, Lim SR, Lee HW, Park JM. Mechanism and kinetics of $\mathrm{Cr}(\mathrm{VI})$ reduction by waste slag generated from iron making industry. Hydrometallurgy 2008;93:72-75.

21. Rice EW, Bridgewater LA. American public health, American water works. Standard methods for the examination of water and wastewater. Washington, D.C.: American Public Health Association; 2012.

22. Vijayaraghavan K, Yun YS. Bacterial biosorbents and biosorption. Biotechnol. Adv. 2008;26:266-291.

23. Fourest E, Volesky B. Contribution of sulfonate groups and alginate to heavy metal biosorption by the dry biomass of Sargassumfluitans. Environ. Sci. Technol. 1996;30:277-282.

24. Graillot A, Bouyer D, Monge S, Robin JJ, Loison P, Faur C. Sorption properties of a new thermosensitive copolymeric sorbent bearing phosphonic acid moieties in multi-component solution of cationic species. J. Hazard. Mater. 2013;260:425-433.

25. Febrianto J, Kosasih AN, Sunarso J, Ju YH, Indraswati N, Ismadji S. Equilibrium and kinetic studies in adsorption of heavy metals using biosorbent: A summary of recent studies. J. Hazard. Mater. 2009;162:616-645.

26. Asuquo E, Martin A, Nzerem P, Siperstein F, Fan X. Adsorption of $\mathrm{Cd}(\mathrm{II})$ and $\mathrm{Pb}$ (II) ions from aqueous solutions using mesoporous activated carbon adsorbent: Equilibrium, kinetics and characterization studies. J. Environ. Chem. Eng. 2017;5:679-698.

27. Al-Degs YS, El-Barghouthi MI, Issa AA, Khraisheh MA, Walker GM. Sorption of $\mathrm{Zn}(\mathrm{II}), \mathrm{Pb}(\mathrm{II})$, and $\mathrm{Co}(\mathrm{II})$ using natural sorbents: Equilibrium and kinetic studies. Water Res. 2006;40:2645-2658.

28. Fu F, Wang Q. Removal of heavy metal ions from wastewaters: A review. J. Environ. Manage. 2011;92:407-418. 